\title{
Research on the Marketing Strategy of Real Estate in Chongqing Under the New Situation
}

\author{
Kefeng Li* \\ School of Tourism Services and Management \\ Chongqing University of Education \\ Chongqing 400060, China
}

\begin{abstract}
From January to February in 2020, the outbreak of the new coronavirus shut down the sales offices of real estate enterprises, and brought the sales performance of real estate enterprises to a low ebb. Typical data such as development investment, new housing construction area, sales situation and funds available dropped significantly. Faced with the new situation, the capital chain of real estate development enterprises is strongly impacted, the sales performance is seriously lagging behind, and the funds withdrawal is difficult. Through questionnaire surveys and big data analysis, real estate development enterprises should act according to how things proceed, increase the penetration of pricing strategies for big promotion, seize online marketing platforms for diversified sales, adopt 4R marketing mode to carry out circle marketing for special groups, increase the planning and research and development of the real estate commodity quality, return to special groups and get quick withdrawal of funds.
\end{abstract}

Keywords—new situation, Chongqing, real estate, marketing

\section{INTRODUCTION}

Aiming at the new situation of the real estate industry during the outbreak of the new coronavirus, a total of 100 questionnaires were issued for investigation, 95 of them were recovered, and the recovery efficiency reached 95\%. The respondents come from different industries, different ages, different educational levels and are representative. The results show that the real estate enterprises can achieve the sales target of 2020 by changing the marketing strategy, adjusting the marketing ideas and marketing through diversified sales channels.

\section{CURRENT Situation OF REAL ESTATE MARKETING IN CHONGQING}

\section{A. Background Introduction of the Real Estate Market in Chongqing}

On January 26, the China Real Estate Association issued a call to the member units and the entire real estate industry to temporarily stop the on-site sales activities at the sales offices until the outbreak is over. In February, the sales offices of real estate enterprises were all shut down, bringing the sales performance of real estate enterprises to a low ebb. Affected by the outbreak of the new coronavirus, typical data such as development investment, new housing construction area, sales situation and funds available dropped significantly.

\section{B. Investment in Real Estate Development Enterprises Decreases, and Sales Performance Declines Substantially}

According to the data of urban supply and demand at the market level, in the key monitoring cities of CRIC, in February, there was no supply in most cities, and the turnover in the major first-tier and second-tier cities dropped by $77 \%$ year-onyear, and the monthly turnover in Guangzhou, Ningbo, Chongqing, $\mathrm{Xi}$ 'an, Nanning, Dalian, Wuhan and other cities dropped by more than $90 \%$ year-on-year. According to the data provided by CRIC Chongqing, in February, among commercial residential transactions in Chongqing, Banan District ranked first in the main urban area with 15,400 square meters, with less than 200 transactions. The second largest transaction volume in Yubei District was 77,800 square meters, with about 60 transactions.

\section{The Real Estate Market Resumes Marketing and Sales, and Sales Performance Gradually Picks Up}

At present, the domestic epidemic situation has been effectively controlled, imported cases have been strictly prevented, production has been resumed in all walks of life, and ordinary people have returned to normal life. However, the sales performance of real estate enterprises fell sharply in the first quarter. Faced with repayment of loans, adjustment of debt structure, supplement of working capital, improvement of financial situation or project investment, all major real estate enterprises are competing to take promotional measures to sell and withdraw funds as soon as possible. The data of CRIC showed that the decline of transactions in Chongqing, Xi'an and other places did not narrowed until April, and it showed a gradual recovery trend.

\section{PROBLEMS OF REAL EstATE MARKETING IN CHONGQING}

\section{A. Housing Prices have Risen too Fast and are Priced at a High Level}

From October 2016 to June 2018, against the background of "destocking", the real estate market in Chongqing experienced a wave of house prices rising too fast. 
According to the survey statistics, consumers have a rational understanding of the housing price. $11.58 \%$ of consumers believe that prices have risen, $42.11 \%$ of consumers hold that prices are steady, $44.21 \%$ of consumers think that prices have slightly declined, and only $2.11 \%$ of consumers think that prices have decreased significantly.

\section{B. The Traditional Offline Marketing Mode of Real Estate Marketing has Lagged Behind}

The traditional real estate marketing promotion is through mass media, including television, radio, newspapers, magazines, outdoor advertising and other public media. Real estate enterprises publish information on these media, and consumers receive real estate information through these media. Second, through the real estate sales center, which is the physical place for real estate enterprises to market, sales personnel spread various real estate information to the consumers, including house type, price, geographic location, supporting facilities, etc., and receive consumers' consultation and feedback, so as to directly understand consumers' attitude and purchase tendency. Third, through e-commerce platforms to propagandize, such as Sina Leju, Sohu Focus Real Estate, Soufun.com, and 58 Tongcheng, but it did not really achieve the effect of network marketing and transaction.

\section{Property Services are not Perfect, and Intelligent Facilities and Equipment are Backward}

During the outbreak of new coronavirus, the property management enterprises undertook part of the work of the community, including the investigation, tracking and registration of the source and access of the owners of the community. When implementing the "closed-off" management in the national community, in addition to the strict control and supervision of the residents' travel, they were also responsible for the coordinated operation of the owner's daily necessities.

The statistical results of the questionnaire data found that only $28.42 \%$ of the consumers are satisfied with the property management companies' management of their anti-epidemic measures during the outbreak of new coronavirus, $41.05 \%$ of consumers believed that property services needed to improve smart management facilities, and $30.53 \%$ of the consumers were not satisfied with the property service, holding that only the basic epidemic prevention management measures had been completed and the prevention effect was not strong. As a result, the property service as the added value of the real estate development enterprise products is particularly important.

\section{The Target Customer Group is not Clear and the Marketing is Lack of Pertinence}

$4 \mathrm{R}$ marketing theory focuses on the interaction and win-win between enterprises and customers under the situation of market maturity and increasingly fierce competition. It not only actively adapts to the needs of customers, but also actively creates demands, integrates marketing with optimization and systematic thinking, forms a unique relationship with customers through association, relationship, response and return, and connects enterprises with customers, and attach importance to customer feedback and reasonable returns to the enterprise, so that the enterprises can form their competitive advantages.

According to the survey data, employees of enterprises and institutions account for $62.11 \%$, civil servants, doctors and teachers account for $15.79 \%$, small and medium-sized business owners account for $16.84 \%$, and company executives account for $5.26 \%$. We can see that enterprise employees and civil servants, doctors and teachers have certain circle culture and common habits. Real estate development enterprises can seize this opportunity to develop customized products for this group and increase the precision marketing.

After the outbreak of the new coronavirus, consumers also have a new understanding of the area where to buy a house. The survey statistics show that only $5.26 \%$ of the consumers select the prosperous commercial districts, $34.74 \%$ of the consumers chose the area 2-3 kilometers away from the business district, $54.74 \%$ of the consumers chose the unprosperous area but with good air, and $5.26 \%$ of the consumers chose the new development district. Consumers have higher demands on the environment and air quality.

\section{E. Product Planning and Design Failed to Keep up with Customer Demand}

During the outbreak of the new coronavirus, people stayed at home for one and a half months, and they found a several main complaining points of the residential districts that affected the health. First, they are not satisfied with the surrounding environment or the high density of the population. The large movement of population in the public areas made the environment noisy. Second, they are not satisfied with the community or the old building or the property service quality. Third, they are not satisfied with the home space and functional layout, and want to change a larger or full equipped house. During the epidemic prevention period at home, the small house, narrow space and high-density living environment make consumers have the impulse to change houses. Real estate development enterprises should grasp the consumer psychology under the "house" economy to carry out the planning, research and development and design of higher and better quality houses.

It can be seen from the statistical data that the impact of housing format, floor area ratio, house type, function and space on people's health has been more and more concerned by buyers. According to the survey data, "I want to change houses after the epidemic" has become the target of the home buyers. Consumers with improved demand have increased. They pay more and more attention to the low floor area ratio and lowdensity housing format. High-rise buildings only account for $5.26 \%$, small high-rise buildings account for $16.68 \%$, and the total proportion of foreign-style houses and villas is $77.9 \%$. The house type and functional space are more reasonable. The large space for public activities such as the opening, depth, height, lighting, and ventilation of the living room, and other independent small spaces will become new demands for buyers 


\section{MARKETING STRATEGY OF REAL ESTATE IN CHONGQING UNDER THE NEW SITUATION}

\section{A. According to the Cost Pricing Method, Real Estate Development Enterprises Increase the Penetration of Pricing Strategy}

The government's positioning that houses are for living in not for speculation makes the present short-term risks faced by the real estate market objectively exist. We should face up to the potential risks and prevent them. Real estate enterprises set reasonable housing sales prices based on cost, market demand, and competition to ensure stable sales targets and withdrawal funds. In the first quarter of 2020, affected by the new coronavirus, the sales performance of Chongqing also dropped significantly, and the quarterly sales targets of major real estate development enterprises failed to be achieved. Based on the cost pricing method, real estate development enterprises adopt penetration pricing strategy to expand market capacity and transform effective demand, which is helpful to capture market share. For real estate commodities with high elasticity of demand, consumers are more sensitive to commodity prices, and their purchase behavior is dominated by the desire for low prices. It is easy to expand the sales market share when they are put into the market at a low price, so as to achieve the sales targets and accelerate the withdrawal of funds.

\section{B. Start Portable E-commerce and Universal Marketing Mode and Real Estate Development Enterprises Increase Their Marketing Promotion Efforts}

Staying at home to prevent the new coronavirus expedites the "housing" economy. Major real estate enterprises start ecommerce and national marketing mode, adjust to selling houses by live broadcast, cooperate with big $\mathrm{V}$, and start live broadcast on the video platforms such as Douyin. Cooperate with the third party portal websites such as Fangtianxia, Leju, Anjuke, etc., to launch the live viewing mode. Rely on their own public account, small procedures, and H5 technology to open "online sales office" and other promotional means to promote sales. Many real estate development enterprises have promised the online deposit subscribe for housing. If the transaction is not successful, consumers can get a refund. Only spending 5,000 Yuan deposit money, consumers can have the priority of their favorite houses. If they are not satisfied, they can get money back without worry. In addition, they can get more discount, more commission, free property fee, preferential parking space, and enjoy the right of no reason to check out or change the name once and other measures, so as to promote sales, solve consumers' purchase worries, and realize national marketing.

\section{Improve Property Management Services, Enhance the Software and Hardware Level of Property Management Enterprises}

The sales target of Longfor Group in 2020 has increased by 40 billion Yuan from 2019, reaching 260 billion. According to financial report data, property management and related services and other income of Longfor Group accounted for 3\% in 2019. Longfor Group can still rank among the top ten real estate enterprises in 2019, which is closely related to Longfor property management and related services. Longfor property is a benchmark enterprise among the property service enterprises in Chongqing. In terms of software, we should do a good job in disinfection and sterilization, owner's appeasement and service. In terms of hardware, it includes the improvement of epidemic prevention facilities and equipment, such as infrared imaging temperature measurement and control and intelligent identification system in and out of the community, which realizes the connection between community intelligence and home intelligence. From the community to home, the whole process is operated through APP, with non-inductive passage and zero-contact public area. It provides the reminders such as the garbage is full, the external is invading and the fire channel is occupied. Intelligent property management will become the standard configuration for real estate development enterprises in the future. Increasing the matching of intelligent facilities and equipment will also improve consumers' experience of buying houses.

\section{Use " $4 R$ " Marketing Mode to Subdivide Target Customers and Increase Precision Marketing}

The reaction mechanism of $4 \mathrm{R}$ marketing theory is interaction and win-win. "Return" is compatible with cost and win-win, and provides a foundation and guarantee for the relationship between the enterprise and consumers. Under the new situation, real estate development enterprises can not only obtain reasonable profit returns, but also make social returns, forming a win-win situation. While undertaking social responsibility and maintaining the core competitiveness of the enterprise, real estate enterprises achieve group marketing of social returns for more than 80000 medical staff and many public security police, community staff, express delivery personnel and other target groups in the front line of fighting the new coronavirus, and improve the market response speed by means of discounts, free property fees and other promotional means to meet the needs of this part of the customers.

\section{E. Demand for Improvement Increases, and Real Estate Development Enterprises Speed up the Planning and $R \&$ $D$ of High-quality Products}

Due to the nature of contact transmission of the novel coronavirus, Ye Qing, deputy director of the Hubei Provincial Statistics Bureau, appealed to the hospital to install a "voiceactivated" elevator for the safety of medical staff and patients Later, the renovated elevator officially opened the "voiceactivated" mode. Medical staffs only need to say the floor, then they can automatically reach their destination. This will enable buyers to put forward higher requirements for some public access facilities and equipment. Real estate development enterprises will improve the air system of the closed public elevators and the "voice-activated" elevators in the products development, which will become the standard configuration of residential housing products. In product planning, they should comply with and meet the potential needs of buyers, which is also a strong guarantee for real estate product planning to strive for market advantages. 


\section{CONCLUSION}

Under the new situation, the real estate development enterprises should be able to quickly feel the changes of the market according to the basic situation of the market, seize the market opportunities, increase marketing efforts, turn around the sales difficulties, and achieve the sales target.

\section{REFERENCES}

[1] Tian Jiefang, Wang Xingguo. Real Estate Marketing [M]. Beijing: Tsinghua University Press, Beijing Jiaotong University Press, 2011. (In Chinese).
[2] Lu Xinhai, Wang Yue. Real Estate Marketing [M]. Beijing: Capital University of Economics and Business Press, 2015. (In Chinese).

[3] CRIC (China) Information Technology Co., Ltd., China Real Estate Information Corporation. Preliminary Planning of Real Estate Development [M]. Beijing: China Economic Publishing House, 2011. (In Chinese).

[4] CRIC (China) Information Technology Co., Ltd., China Real Estate Information Corporation Network. (In Chinese).

[5] Kotler. Market Management [M]. 14th Global Edition. Beijing: China Renmin University Press, 2012. (In Chinese).

[6] https://cq.leju.com/2020-03-20 13:08:50, source: Leju House.

[7] https://cq.qq.com/ Local•Industry Tencent Dayu [Weibo] 2020-03-19 17:14.

[8] http://www.cricchina.com/Home/Index_V2.

[9] https://cq.focus.cn/zixun/6220ce7ea07bdb25.html 